KATARZYNA EGER ${ }^{1}$

\title{
Polecenie a świadczenie na rzecz osoby trzeciej w umowie darowizny
}

\section{Streszczenie}

Artykuł dotyczy możliwości zastosowania w umowie darowizny dwóch konstrukcji prawnych: polecenia (art. 893 k.c.) oraz zobowiązania na rzecz osoby trzeciej (art. 393 k.c.). Autorka analizuje różnice pomiędzy tymi dwiema konstrukcjami prawnymi i rozważa zasady prawidłowej subsumpcji. Przedmiotem rozważań jest także kwestia możliwości skutecznego dochodzenia realizacji polecenia na drodze sądowej.

Słowa kluczowe: darowizna, polecenie, zobowiązanie na rzecz osoby trzeciej, zaskarżalność

1 Mgr Katarzyna Eger - adwokat, uczestniczka prawniczego seminarium doktoranckiego w Kolegium Prawa Akademii Leona Koźmińskiego, Warszawa, Polska (e-mail: katarzynakopczynska@eger.com.pl). 


\title{
KATARZYNA EGER
}

\section{Instruction or contract for the benefit of third party under donation agreement}

\begin{abstract}
In the article the author analyses the possibility of using under the donation agreement two different legal constructions: instruction (article 893 of Polish Civil Code) and contract for the benefit of third party (article 393 of Polish Civil Code). The author analyses the differences between these two legal constructions and discusses the criteria of correct subsumption. Furthermore the author considers whether the third party is entitled to demand the instruction to be followed in front of the court.
\end{abstract}

Keywords: donation, instruction, commitment to a third party 
W obrocie, w szczególności w relacjach rodzinnych, dość często zdarza się, że darczyńca darowuje określoną rzecz jednej osobie, zobowiązując ją jednocześnie do spłaty na rzecz osób trzecich. Typowym przykładem takiej sytuacji jest dokonanie przez rodziców darowizny gospodarstwa rolnego na rzecz jednego z dzieci z jednoczesnym zobowiązaniem obdarowanego do spłaty na rzecz rodzeństwa. Rodzice u schyłku życia chcą rozdysponować swoim majątkiem równo traktując swoje dzieci, ale przy jednoczesnym zachowaniu jedności gospodarstwa. Kwalifikacja prawna takich umów rodzi poważne wątpliwości w doktrynie i orzecznictwie. Tego rodzaju umowa może zostać zakwalifikowana jako darowizna z poleceniem (art. 893 k.c.) albo jako darowizna z zastrzeżeniem świadczenia na rzecz osoby trzeciej (art. 393 §1 k.c.). To rozróżnienie rodzi doniosłe skutki prawne. W przypadku zakwalifikowania postanowienia umownego jako polecenia wyłączona jest co do zasady możliwość dochodzenia na drodze sądowej realizacji tego polecenia przez osobę, która ma uzyskać z niego korzyść. W przypadku zaś zakwalifikowania postanowienia umownego jako zobowiązania na rzecz osoby trzeciej taka możliwość istnieje. W niniejszym artykule chciałabym przeanalizować zasady rozróżnienia obu instytucji oraz poddać krytyce orzecznictwo kwestionujące w ogóle możliwość dochodzenia na drodze sądowej realizacji polecenia.

\section{Rys historyczny}

Na wstępie warto nadmienić, że instytucja zbliżona do polecenia w odniesieniu do prawa spadkowego funkcjonowała już w prawie rzymskim jako tzw. fideikomis. W fideikomisie spadkodawca prosił kogoś, kto otrzymał cokolwiek ze spadku, aby przekazał określone dobra osobie trzeciej, zazwyczaj nazywanej fideikomisariuszem. Przedmiot prośby spadkodawcy mógł być bardzo zróżnicowany. Żądanie mogło dotyczyć wyzwolenia niewolnika (tzw. fideikomis wolności lub wyzwolenie fideikomisarne), przekazania poszczególnych dóbr (fideikomis syngularny) lub nawet dotyczyć całości spadku lub wyrażonej ułamkiem jego części (fideikomis uniwersalny) ${ }^{2}$. Początkowo fideikomis nie miał charakteru zaskarżalnego, co oznaczało brak możliwości dochodzenia realizacji przedmiotu fideikomisu na drodze

2 Zob. szerzej F. Longchamps de Berier, O elastyczności prawa spadkowego: fideikomis uniwersalny w klasycznym prawie rzymskim, Warszawa 2006, s. 11-12. 
sądowej. Wykonanie żądania było oparte na rzymskiej fides rozumianej w szczególności jako lojalność i wierność danemu słowu. Fideikomis zyskał ochronę prawną za czasów Oktawiana Augusta, który w pierwszej kolejności nakazał konsulom, aby w tym celu doprowadzili do wypełnienia kilku fideikomisów na drodze administracyjnej, co następnie rozwinęło się w instytucję tzw. assidua iurisdictio. Procedura, w której dochodzono wypełnienia fideikomisów, stanowiła pierwszą cognitio extra ordinem. Za czasów Justyniana zrównano fideikomisy z legatami, czyli zapisami testamentowymi ${ }^{3}$.

W kodeksie zobowiązań wprost została uregulowana kwestia tzw. darowizny obciążliwej. Art. 354 § 2 kodeksu zobowiązań stanowił, że darczyńca może obciążyć obdarowanego obowiązkiem spełnienia oznaczonego świadczenia. Dalej art. $362 \mathrm{w}$ kolejnych czterech paragrafach precyzowal, że darczyńca ma prawo domagać się spełnienia świadczenia obciążającego obdarowanego, jeżeli wykonał swe zobowiązania, wynikające z umowy darowizny, a świadczenie nie ma na celu wyłącznie korzyści obdarowanego. Prawo to przechodziło na spadkobierców darczyńcy. Jeżeli świadczenie dodatkowo leżało w interesie publicznym, to spełnienia świadczenia mogła żądać po śmierci darczyńcy także właściwa władza. Wreszcie $\S 4$ wyraźnie wskazywał, że osoba trzecia, która odnosi korzyść ze świadczenia, może się domagać jego spełnienia według przepisów o umowach na rzecz osób trzecich. Dodatkowo art. 363 § 1 uzupełniał regulację instytucji, stanowiąc, że jeżeli obdarowany nie spełniał świadczenia bez uzasadnionej przyczyny, to darczyńca lub jego spadkobiercy mogli żądać zwrotu przysporzenia majątkowego według przepisów o niesłusznym wzbogaceniu o tyle, o ile to przysporzenie musiałoby być użyte na spełnienie świadczenia. Natomiast o świadczeniu na rzecz osoby trzeciej traktował art. $92 \S 1$ kodeksu zobowiązań, stanowiąc, że kto, zawierając umowę, zastrzegł świadczenie na rzecz osoby trzeciej, osoba ta, w braku odmiennej umowy, może wprost od dłużnika żądać spełnienia świadczenia.

Kodeks cywilny nie przejął w prost koncepcji darowizny obciążliwej. Wprowadził natomiast pojęcie darowizny z poleceniem. Zgodnie z art. 893 k.c. darczyńca może włożyć na obdarowanego obowiązek oznaczonego działania lub zaniechania, nie czyniąc nikogo wierzycielem (polecenie). Art. 894 k.c. stanowi dalej, że darczyńca, który wykonał zobowiązanie wynikające z umowy darowizny, może żądać wypełnienia polecenia, chyba że ma ono wyłącznie na celu korzyść obdarowanego. Po śmierci darczyńcy wypełnienia polecenia mogą żądać spadkobiercy darczyńcy, a jeżeli polecenie ma na względzie interes społeczny - także właściwy organ państwowy. Zgodnie z art. $895 \S 1$ k.c. obdarowany może odmówić wypełnienia polecenia, jeżeli jest to usprawiedliwione wskutek istotnej zmiany stosunków.

3 Ibidem, s. 6. 
Natomiast instytucja zobowiązania na rzecz osoby trzeciej została przejęta z kodeksu zobowiązań do art. 393 k.c.

W aktualnym stanie prawnym funkcjonują więc obok siebie instytucje polecenia i świadczenia na rzecz osoby trzeciej. Przy czym w przypadku polecenia do kręgu osób uprawnionych do żądania spełnienia świadczenia należy tylko darczyńca lub jego spadkobiercy, ewentualnie właściwy organ państwowy. W przypadku zobowiązania na rzecz osoby trzeciej wykonania zobowiązania może żądać zarówno darczyńca, jak i ta osoba trzecia. W przypadku zatem darowizny zawierającej postanowienie o obowiązku obdarowanego spełnienia określonego świadczenia na rzecz osoby trzeciej istnieje możliwość zakwalifikowania umowy zarówno jako polecenia (art. 893 k.c.), jak i świadczenia na rzecz osoby trzeciej (art. 393 § 1 k.c.). W orzecznictwie i w doktrynie nie analizowano dotąd szczególowo zasad prawidłowej subsumpcji w tym zakresie.

\section{Zaskarżalność polecenia}

Art. 894 k.c. określa krąg osób, które mogą żądać wypełnienia polecenia, określając go jako darczyńcę, który wykonał zobowiązanie wynikające z umowy darowizny, a po jego śmierci spadkobierców darczyńcy, a jeżeli polecenie ma na względzie interes społeczny - także właściwy organ państwowy. Wyjątkiem jest sytuacja, gdy polecenie ma wyłącznie na celu korzyść obdarowanego. Wówczas nie ma podmiotu, który mógłby żądać wykonania polecenia. Na pierwszy rzut oka wydawałoby się, że kwestia możliwości dochodzenia realizacji polecenia przez osoby z powyższego kręgu osób uprawnionych jest oczywista i nie powinna budzić wątpliwości. Sytuacja jest jednak znacznie bardziej skomplikowana.

W postanowieniu z dnia 19 kwietnia 2002 r. Sąd Najwyższy wyraził pogląd przeciwny: „Powszechnie przyjmuje się przy tym, że nałożenie na obdarowanego lub spadkobiercę polecenia, także majątkowego, nie prowadzi do powstania stosunku zobowiązaniowego analogicznego jak wynikający z innych zdarzeń prawnych, z którymi ustawa łączy taki skutek (zawarcie umowy, wyrządzenie szkody, zapis testamentowy). Osoba, która odnosi z polecenia korzyść, nie jest wierzycielem, lecz beneficjariuszem. Taki wniosek wywodzi się z charakteru prawnego polecenia, którego nałożenie na określoną osobę (obdarowanego, spadkobiercę) prowadzi do powstania zobowiązania naturalnego (niezupełnego). Takie stosunki zobowiązaniowe charakteryzują się niemożliwością dochodzenia od dłużnika należnego świadczenia na drodze sądowej. »Niezupełność« zobowiązania wyraża się w odjęciu uprawnionemu możliwości skorzystania z przymusu państwowego w celu uzyskania należnego świadczenia, jednak spełnienie świadczenia przez zobowiązanego 
nie jest świadczeniem nienależnym. Oznacza to, że zarówno gdy chodzi o polecenie przy darowiźnie, jak i przy poleceniu testamentowym, określony krąg podmiotów może domagać się od obciążonego powinnego zachowania się wynikającego z treści polecenia, jednak podmioty te nie mogą skorzystać z przymusu państwowego w celu zmuszenia obciążonego do takiego zachowania się" ${ }^{\prime \prime}$.

$\mathrm{W}$ doktrynie wyrażony $\mathrm{w}$ tym postanowieniu pogląd spotkał się z krytyką. P. Księżak zauważył, że „nie do przyjęcia jest stwierdzenie Sądu Najwyższego, jakoby realizacja obowiązku wynikającego z polecenia nie mogła być wymuszona, a droga sądowa była wyłączona. Są to tezy poddające $w$ wątpliwość ratio instytucji polecenia (...). Posłużenie się przez ustawę słowami »może żądać« oznacza istnienie prawa (niekoniecznie roszczenia w znaczeniu materialno prawnym), które może być zrealizowane za pomocą przymusu państwowego. [...] jeśli nie ma żadnej sankcji ani możliwości stosowania przymusu państwowego, to nie ma sensu wskazywanie przez ustawę podmiotów, które »mogą żądać wykonania polecenia«. Niezaopatrzoną w żadną sankcję prośbę o wykonanie polecenia skierować do obciążonego może przecież każdy (...) Pogląd o możliwości dochodzenia przez wskazane osoby wypełnienia polecenia w drodze powództwa przeważa w doktrynie $^{\prime \prime}$. Niektórzy autorzy wskazują, że podstawę dochodzenia realizacji polecenia mogą stanowić przepisy o bezpodstawnym wzbogaceniu. Podnoszą, że osoby uprawnione do żądania polecenia mogą żądać zwrotu korzyści majątkowej utrzymującej się w mieniu obdarowanego wskutek niewypełnienia polecenia ${ }^{6}$. Inni przedstawiciele doktryny są natomiast zgodni z powyżej zaprezentowanym stanowiskiem Sądu Najwyższego ${ }^{7}$.

Dokonując analizy powyższego zagadnienia, należy wyjść od pojęcia normatywności prawnej. W doktrynie ugruntowany jest pogląd, że normatywność to powinność zachowania, która towarzyszy każdemu zobowiązaniu. Normatywność ta nie zawsze ma jednak charakter normatywności prawnej, tzn. zapewniającej możliwość skutecznego dochodzenia wykonania zobowiązania na drodze sądowej (zobowiązanie prawne). Zobowiązania, którym nie towarzyszy normatywność prawna, to w szczególności zobowiązania naturalne lub niezupełne. Przy czym podkreśla się, że w sytuacji, gdy powinność danego zachowania jest określona

4 Postanowienie SN z dnia 19 kwietnia 2002 r., III CZP 19/02LEX nr 74583, Prok.iPr.-wkł. 2003/1/34, OSP 2003/10/123.

5 P. Księżak, Żądanie wykonania polecenia, PS 2006, 4, s. 58-59; podobnie K. Sokołowski, Darowizna $z$ poleceniem a negotium mixtum cum donatione w praktyce notarialnej, „Rejent” 2011, 4, s. 51 i nast.

6 S. Grzybowski, [w:] System prawa cywilnego, t. III, cz. 2, Wrocław 1976, s. 244; M. Wilejczyk. Darowizna obciążona poleceniem, „Państwo i Prawo” 2013, 5, s. 74-75.

7 Tak M. Safjan, [w:] K. Pietrzykowski (red.), Kodeks cywilny. Tom II. Komentarz, Warszawa 2004, s. 607. 
przez przepisy prawa albo inny porządek prawny traktowany na równi z przepisami (prawo zwyczajowe), mamy do czynienia z zobowiązaniem prawnym ${ }^{8}$. Regułą jest, że odpowiedzialność towarzyszy długowi, co oznacza, że wierzycielowi przysługuje prawo dochodzenia wykonania zobowiązania $w$ procesie 9 . R. Longchamps de Berier wywodzi powyższą zasadę bezpośrednio z przepisu określającego zobowiązanie, w tej części, w której przepis stanowi, że dłużnik powinien świadczenie spełnić. Zdaniem tego autora wierzytelność nie byłaby prawem podmiotowym, gdyby była pozbawiona ochrony prawnej ${ }^{10}$. Inni przedstawiciele doktryny krytykują ten pogląd. P. Machnikowski wskazuje, że powyższa zasada, choć nie wynika bezpośrednio z przepisów prawa, to jednakże stanowi konsekwencję wykładni ogółu przepisów prawa materialnego i procesowego. Autor dodaje, że potwierdzeniem istnienia tej zasady jest precyzyjne określenie $\mathrm{w}$ przepisach przysługujących od niej wyjątków ${ }^{11}$. Za trafniejszy uważam pogląd P. Machnikowskiego z uwagi na brak wyraźnego wskazania w przepisach możliwości dochodzenia na drodze sądowej realizacji zobowiązań. Niewątpliwie jednak przedstawiciele doktryny i orzecznictwo są zgodni co do tego, że zasadą jest możliwość dochodzenia na drodze sądowej wykonania zobowiązania prawnego. Wyjątki zaś od tej zasady wymagają precyzyjnego skodyfikowania. Trzeba przy tym nadmienić, że zobowiązania prawne niezupełne (naturalne) to takie, które są wyznaczone przez przepisy prawa. Kategoria ta nie obejmuje zobowiązań o charakterze tylko moralnym oraz tzw. zobowiązań towarzyskich wyznaczanych przez normy obyczajowe tworzone przez oświadczenia stron, z których treści lub okoliczności można wnioskować o braku zamiaru wywołania skutków prawnych ${ }^{12}$. Do zobowiązań naturalnych bezspornie zalicza się zobowiązania, które uległy przedawnieniu oraz zobowiązania z gry lub zakładu, które nie były zakazane lub nierzetelne, ale nie były też prowadzone na podstawie stosownego zezwolenia organu państwowego. Należy jednak od razu dodać, że zobowiązania przedawnione mogą uzyskać ochronę prawną w postaci orzeczenia sądowego, jeżeli pozwany nie

8 E. Łętowska, [w:] E. Łętowska (red.), System Prawa Prywatnego. Tom 5. Prawo zobowiązań - część ogólna, Warszawa 2006, s. 5.

9 Szerzej na temat rozróżnienia wierzytelności do roszczenia zob. I. Karasek-Wojciechowicz, Roszczenie o wykonanie zobowiązania z umowy zgodnie z jego treścia, Warszawa 2014, s. 85-137.

10 W odniesieniu do art. $2 \S 1$ kodeksu zobowiązań: R. Longchamps de Berier, Uzasadnienie projektu kodeksu zobowiazań uwzględnieniem ostatecznego tekstu kodeksu. Art. 1-167, Warszawa 1934, s. 6.

11 P. Machnikowski, [w:] E. Łętowska (red.), System Prawa Prywatnego. Tom 5. Prawo zobowiąań - część ogólna, Warszawa 2006, s. 160-161.

12 A. Ohanowicz, [w:] A. Ohanowicz, Z. Górski, Zarys prawa zobowiązań, Warszawa 1970, s. 22; Z. Radwański, [w:] Z. Radwański (red.), System Prawa Prywatnego, Tom 2, Prawo cywilne-część ogólna, Warszawa 2008, s. 24-28. 
podniesie w toku procesu zarzutu przedawnienia. Kwestia pochodzenia zobowiązania z gry lub zakładu brana jest zaś przez sąd pod uwagę z urzędu ${ }^{13}$.

Przyjrzymy się bliżej sformułowaniom ustawy wprowadzającym ograniczenie możliwości realizacji zobowiązania na drodze sądowej. Zgodnie z art. 413 § 1 k.c. kto spełnia świadczenie z gry lub zakładu, nie może żądać zwrotu, chyba że gra lub zakład były zakazane albo nierzetelne. $\S 2$ stanowi zaś, że roszczeń z gry lub zakładu można dochodzić tylko wtedy, gdy gra lub zakład były prowadzone na podstawie zezwolenia właściwego organu państwowego. Natomiast art. 117 §2 k.c. stanowi, że po upływie terminu przedawnienia ten, przeciwko komu przysługuje roszczenie, może uchylić się od jego zaspokojenia, chyba że zrzeka się korzystania z zarzutu przedawnienia. Jak zatem widać, przepisy bardzo wyraźnie w powyższych dwóch przypadkach wskazują albo na brak możliwości dochodzenia realizacji roszczenia, albo na możliwość uchylenia się przez dłużnika z obowiązku realizacji zobowiązania.

Przeanalizujmy teraz treść art. 893 k.c. Zgodnie z jego brzmieniem darczyńca może włożyć na obdarowanego obowiązek oznaczonego działania lub zaniechania, nie czyniąc nikogo wierzycielem. Zgodnie zaś z art. 894 § 1 k.c. darczyńca, który wykonał zobowiązanie wynikające z umowy darowizny, może żądać wypełnienia polecenia, chyba że ma ono wyłącznie na celu korzyść obdarowanego. § 2 stanowi uzupełniająco, że po śmierci darczyńcy wypełnienia polecenia mogą żądać spadkobiercy darczyńcy, a jeżeli polecenie ma na względzie interes społeczny - także właściwy organ państwowy. Dalej w art. 895 § 1 k.c. znajduje się ograniczenie stanowiące, że obdarowany może odmówić wypełnienia polecenia, jeżeli jest to usprawiedliwione wskutek istotnej zmiany stosunków. Powołane przepisy w swojej konstrukcji diametralnie różnią się od precyzyjnego art. $413 \S 2$ k.c. oraz 117 $\S 2$ k.c. Potraktowanie polecenia jako zobowiązania naturalnego w mojej ocenie jest przejawem niedopuszczalnej wykładni contra legem. Dla postawienia tezy o niepełnym charakterze zobowiązania konieczne byłoby wyraźne wskazanie ustawodawcy o braku możliwości dochodzenia roszczenia na drodze sądowej. Określenie „nie czyniąc nikogo wierzycielem” takiego wskazania nie stanowi. Przywołana treść przepisu wyłącza jedynie prawa beneficjariusza do żądania realizacji polecenia na drodze sądowej. Natomiast nie odnosi się w żadnym razie do darczyńcy. Kierując się zasadą racjonalności ustawodawcy, byłoby pozbawione sensu wskazywanie kręgu osób uprawnionych do żądania realizacji polecenia, w sytuacji gdyby to żądanie miało mieć charakter jedynie moralny, pozbawiony ochrony prawnej. Możliwość przymusowego wyegzekwowania obowiązków prawnych jest istotną cechą tych obowiązków i fundamentem konstrukcji systemu

13 Szerzej na ten temat P. Machnikowski, op. cit., s. 165. 
prawnego. Odstępstwa od tej reguły dopuszczalne są tylko wyjątkowo i powinny wprost wynikać z przepisu ustawy. Warto dodać, że sformułowanie z art. 894 $\S 1$ i 2 k.c. co do możliwości żądania jest tożsame ze sformułowaniem zawartym w art. $353 \S 1$ k.c. stanowiącym, że „wierzyciel może żądać” od dłużnika świadczenia. W przypadku tego ostatniego przepisu możliwość dochodzenia spełnienia świadczenia nie budzi żadnych wątpliwości.

Podsumowując, uważam, że polecenie określone w art. 893 k.c. nie jest pozbawione ochrony prawnej. Ograniczony jest jedynie krąg podmiotów, które mogą żądać realizacji polecenia na drodze sądowej, tj. darczyńca, który wykonał darowiznę, a po jego śmierci jego spadkobiercy i ewentualnie właściwy organ państwowy, gdy polecenie ma na względzie interes społeczny. Odmienna wykładnia byłaby sprzeczna z jasnym i klarownym brzmieniem przepisu oraz tradycją tej instytucji sięgającą czasów rzymskich. Polecenie różni się więc tym od zobowiązania na rzecz osoby trzeciej, że w przypadku polecenia ten, na czyją korzyść zostało one zastrzeżone, nie może dochodzić jego realizacji na drodze sądowej (za wyjątkiem sytuacji, gdy występuje jako spadkobierca darczyńcy). W przypadku instytucji z art. 393 k.c. osoba trzecia może zaś dochodzić w procesie realizacji zastrzeżonego na jej rzecz zobowiązania, choć nie była stroną zawartej umowy.

\section{Dopuszczalność zastrzeżenia w umowie darowizny zobowiązania do świadczenia na rzecz osoby trzeciej}

Drugim problemem, jaki zarysowuje się na tle omawianego zagadnienia, jest kwestia ustalenia, czy w umowie darowizny dopuszczalne jest posłużenie się wyłącznie konstrukcją polecenia, czy też dopuszczalne jest także wykorzystanie konstrukcji zobowiązania na rzecz osoby trzeciej. Zarówno w judykaturze, jak i w doktrynie przyjmuje się dopuszczalność konstruowania umowy darowizny w postaci:

umowy darowizny z poleceniem (zastosowanie znajduje przepis art. 893 k.c.),

$\square$ umowy darowizny z zastrzeżeniem świadczenia na rzecz osoby trzeciej tzw. negotium mixtum cum donatione (zastosowanie znajduje przepis art. 393 $\S 1$ k.c.).

Obie konstrukcje są dopuszczalne i powszechnie stosowane w praktyce. Za powyższym stanowiskiem opowiada się zarówno ugruntowane orzecznictwo, jak i jednolite poglądy doktryny. W szczególności Sąd Najwyższy prezentuje w tej mierze jednolitą linię orzeczniczą:

$\square$ „Obciążenie w umowie darowizny lub dożywocia nabywcy nieruchomości rolnej obowiązkiem zapłaty na rzecz osoby trzeciej określonej kwoty pie- 
niężnej jest dopuszczalne" (uchwała SN z dnia 11 marca 1970 r., III CZP 28/70, OSNC 1971/10/171);

$\square$ „Dopuszczalne jest obciążenie przez darczyńcę zstępnego, któremu podarował on gospodarstwo rolne, określonym świadczeniem pieniężnym na rzecz innej osoby - niezależnie od tego, czy posiada ona warunki do dziedziczenia gospodarstwa rolnego" (wyrok SN z dnia 26 marca 1970 r., III CRN 78/70, OSNC 1971/2/33);

$\square$ „Mimo że kodeks cywilny nie przejął przepisu art. 354 § 2 k.z., darczyńcy wolno obciążyć drugą stronę umowy darowizny (obdarowanego) obowiązkiem spełnienia oznaczonego świadczenia na rzecz osoby trzeciej, przez co czyni on tę osobę wierzyciela obdarowanym" (wyrok SN z dnia 21 marca 1973 r., III CRN 40/73, OSNC 1974/2/26).

Nie można przy tym pominąć cytowanego już postanowienia Sądu Najwyższego z dnia 19 kwietnia 2002 roku (III CZP 19/02, OSP 2003/10/123). Jak wcześniej wskazywałam, Sąd Najwyższy powziął wówczas poważne wątpliwości co do kręgu podmiotów uprawnionych w stanie faktycznym sprawy do wystąpienia przeciwko obdarowanemu z żądaniem wypełnienia polecenia (problem tzw. „zaskarżalności” polecenia). Sąd Najwyższy na marginesie rozważań, wykraczając poza ramy postawionego pytania prejudycjalnego, uznał za konieczne zasugerowanie Sądowi stawiającemu pytanie rozważenie interpretacji zapisów umowy jako zobowiązania na rzecz osoby trzeciej, podnosząc: „Na marginesie jedynie można natomiast odnieść się do kwestii poruszonej w uzasadnieniu postanowienia Sądu Okręgowego, jaką stanowi dopuszczalność objęcia treścią umowy darowizny świadczenia na rzecz osoby trzeciej. Co do zasady takie ukształtowanie umowy należy uznać za dopuszczalne, chociaż powstanie wówczas pytanie, czy mamy do czynienia nadal $\mathrm{z}$ umową darowizny, czy też z umową mieszaną. Rozstrzygnięcie tego zagadnienia prawnego nie jest jednak możliwe, gdyż nie zostało ono objęte treścią postanowienia Sądu Okręgowego. Sąd Najwyższy wypowiadał się zresztą w tej kwestii (por. wyrok z 21 marca 1973 r., III CRN 40/73, OSNCP 1974, nr 2, poz. 26 oraz uchwałę z 11 marca 1970 r., III CZP 28/70, OSNCP 1971, nr 10, poz. 171)". W cytowanym powyżej orzeczeniu Sąd Najwyższy potwierdził aktualność poglądów wyrażonych we wskazanych powyżej orzeczeniach z lat 70 .

Pogląd ten aprobuje również doktryna. L. Stecki wskazał, że w praktyce w związku z dokonywanymi darowiznami coraz częściej stosuje się nie klasyczne polecenie, lecz dodatkowe zobowiązanie, stosownie do którego obdarowany ma spełnić oznaczone świadczenie na rzecz osoby trzeciej pojmowanej przez strony jako wierzyciel. Autor wyjaśnił, że obok darowizny z poleceniem, może także istnieć darowizna połączona z umową o spełnienie świadczenia na rzecz osoby trzeciej, 
jako rodzaj umowy o mieszanym charakterze ${ }^{14}$. Podobnie wypowiedział się M. Niedośpiał, wyjaśniając: „W umowie darowizny można zastrzec różne świadczenia na rzecz darczyńcy lub osób trzecich, np. obowiązek spłat na rzecz oznaczonych osób trzecich. W tym ostatnim przypadku, umowa w tej części jest umową na rzecz osoby trzeciej (art. 393 k.c.) [...] Dopuszczalna jest [...] tzw. darowizna obciążliwa, wynika to ze swobody umów (art. $353^{1}$, art. 58 k.c.). W umowie takiej darczyńca nakłada na obdarowanego obowiązek określonego świadczenia na rzecz darczyńcy lub osoby trzeciej. Podmioty te mają wierzytelność o spełnienie świadczenia"15. Także M. Safjan opowiedział się za możliwością stosowania konstrukcji świadczenia na rzecz osoby trzeciej w powiązaniu z umową darowizny: „Nie stanowi polecenia nałożenie na obdarowanego obowiązku świadczenia na rzecz osoby trzeciej, która staje się jego wierzycielem (por. wyr. SN z 21.03.1973 r., III CRN 40/73, OSNCPiUS 1974, Nr 2, poz. 26). Tego rodzaju konstrukcja będzie przybierać najczęściej postać umowy mieszanej (negotium mixtum cum donatione)"16.

W tym kontekście należy wziąć także pod uwagę kwestię kauzalności umów. Niewątpliwie umowa o zobowiązanie na rzecz osoby trzeciej jak każda inna umowa ma charakter kauzalny. Zawarcie umowy na rzecz osoby trzeciej powoduje, że pomiędzy stronami tej umowy a osobą trzecią zachodzą łącznie trzy stosunki obligacyjne: pokrycia, zapłaty i waluty. Stosunek pokrycia zachodzi między wierzycielem i dłużnikiem (w omawianym przypadku pomiędzy darczyńcą a obdarowanym). Stosunek zapłaty (wykonania) zachodzi między dłużnikiem (obdarowanym) a osobą trzecią. Stosunek waluty zachodzi zaś między wierzycielem (darczyńcą) a osobą trzecią ${ }^{17}$. Kauzalność musi dotyczyć wszystkich trzech stosunków. Niewątpliwie konstrukcja zobowiązania na rzecz osoby trzeciej wykorzystywana jest w praktyce najczęściej w celu ułatwienia obrotu gospodarczego. Dzięki niej przez spełnienie jednego świadczenia można od razu zaspokoić dwóch dłużników i dokonać dwóch przysporzeń: pomiędzy dłużnikiem i wierzycielem oraz pomiędzy wierzycielem a osobą trzecią ${ }^{18}$. Powyższe nie oznacza jednak, że brak zobowiązania pomiędzy wierzycielem (darczyńcą) a osobą trzecią (na rzecz której zastrzeżono świadczenie) wyłącza możliwość posłużenia się konstrukcją

14 L. Stecki, Glosa do wyroku SN z dnia 21 marca 1973 r., III CRN 40/73, NP 1975, Nr 10-11, s. 1479-1480.

15 M. Niedośpiał, Glosa do wyroku SA w Katowicach $z$ dnia 3 lutego 1995 r., I ACr 656/94, OSA 1997, Nr 10, s. 75 .

16 M. Safjan, [w:] K. Pietrzykowski (red.), Kodeks cywilny, Tom II..., op. cit., s. 606; podobnie także S. Rejman, [w:], Z. Resich (red.), Kodeks cywilny. Komentarz, t. 2, Warszawa 1972, s. 1739; A. Kubas, Umowa na rzecz osoby trzeciej, ZNUJ, Warszawa-Kraków 1976, Prace Prawnicze, z. 78, s. 135-137.

17 A. Rzetecka-Gil, Kodeks cywilny. Komentarz. Zobowiazania - część ogólna, wydanie tylko elektroniczne LEX/el., 2011, komentarz do art. 393 k.c.

18 M. Bednarek, [w:] E. Łętowska (red.), System Prawa Prywatnego..., op. cit., s. 877. 
z art. 393 k.c. Kauzą w ramach stosunku waluty nie musi być wcale chęć zwolnienia się z długu przez darczyńcę (causa solvendi). W doktrynie i orzecznictwie przyjmuje się, że także chęć obdarowania kogoś (causa donandi) może stanowić przyczynę dokonania zastrzeżenia na rzecz osoby trzeciej w ramach stosunku waluty. Takie stanowisko zajął m.in. Sąd Apelacyjny w Lublinie w wyroku z dnia 24 września 2014 r.: "Zawarcie umowy na rzecz osoby trzeciej powoduje, że pomiędzy stronami tej umowy a osobą trzecią zachodzą łącznie trzy stosunki obligacyjne: pokrycia, zapłaty i waluty. Stosunek waluty zachodzi między wierzycielem a osobą trzecią. Ten stosunek obligacyjny, istniejący w momencie zawarcia umowy na rzecz osoby trzeciej lub mający powstać z chwilą spełnienia świadczenia na rzecz osoby trzeciej przez dłużnika, wyjaśnia przyczynę, dla której doszło do zastrzeżenia świadczenia na rzecz osoby trzeciej w umowie podstawowej. Przyczynę prawną przysporzenia na rzecz osoby trzeciej może stanowić wola obdarowania osoby trzeciej przez wierzyciela (causa donadi)"19. Także M. Bednarek podzielił ten pogląd: „Wierzyciel za pomocą konstrukcji pacti in favorem tertii może zrealizować rozmaite cele: 1) może zwolnić się z obciążającego go zobowiązania wobec osoby trzeciej [...]; 2) w zamian za świadczenie spełnione przez dłużnika wierzyciel może chcieć uzyskać od osoby trzeciej świadczenie wzajemne [...]; 3) wierzyciel może chcieć obdarować osobę trzecią - wówczas przyczynę prawną przysporzenia stanowi causa donandi"20.

Podsumowując tę część rozważań, należy uznać, że istnieje możliwość zastosowania w umowie darowizny zarówno konstrukcji polecenia, jak i świadczenia na rzecz osoby trzeciej. W dalszej części należy rozważyć zasady, jakimi należy się kierować przy rozróżnianiu obu konstrukcji prawnych.

\section{Rozróżnienie pomiędzy poleceniem a zobowiązaniem na rzecz osoby trzeciej}

Po postawieniu tezy o dopuszczalności wykorzystania w umowie konstrukcji zarówno polecenia, jak i zobowiązania na rzecz osoby trzeciej, wyłania się problem właściwej subsumpcji. Oczywiście w praktyce będą sytuacje, gdy strony w treści umowy wyraźnie wskażą, że ich zamiarem było wykorzystanie instytucji polecenia, powołując się art. 893 k.c. albo zobowiązania na rzecz osoby trzeciej, przywołując art. 393 k.c. Precyzyjnym wskazaniem na zamiar ustanowienia polecenia byłoby też posłużenie się zwrotem w stosunku do osoby, która ma uzyskać świadczenie o nieczynieniu jej wierzycielem. Problematyczną będzie kwestia, gdy brzmienie

\footnotetext{
19 Wyrok Sądu Apelacyjnego w Lublinie z dnia 24 września 2014 r., I ACa 355/14, LEX nr 1527095.

20 M. Bednarek, op. cit., s. 891-892.
} 
umowy nie będzie tak ściśle uwidaczniać zamiaru stron, a umowa darowizny będzie jednocześnie przewidywać świadczenie dla osoby trzeciej.

Tak jak w przypadku każdej umowy, jej wykładni należy dokonywać zgodnie $z$ art. $65 \S 2$ k.c. Pierwszeństwo należy zatem przydać zamiarowi stron i celowi umowy, aniżeli opierać się na jej dosłownym brzmieniu. W doktrynie wskazuje się, że na tle art. $65 \S 2$ k.c. można wyodrębnić trzy poziomy wykładni umowy: dosłowne (literalne) brzmienie umowy, treść oświadczeń woli ustalaną przy zastosowaniu kryteriów zawartych w art. $65 \S 1$ k.c. oraz sens oświadczeń woli ustalany poprzez badanie zgodnego zamiaru stron i celu umowy ${ }^{21}$. To ten ostatni poziom powinien mieć priorytet ${ }^{22}$.

E. Rott-Pietrzyk słusznie uznała, że art. 65 k.c. stanowi zbiór dyrektyw interpretacyjnych w postaci:

nakazu uwzględniania okoliczności (tj. kontekstu sytuacyjnego),

$\square$ zakazu literalnej interpretacji,

- nakazu uwzględniania zamiarów i celów stron,

$\square$ nakazu uwzględniania określonych zasad moralnych przez odniesienie do zasad współżycia społecznego,

$\square$ nakazu uwzględnienia ustalonych zwyczajów ${ }^{23}$.

Trzeba mieć przy tym na uwadze fakt, że znaczna część problematycznych umów zawierana jest $\mathrm{w}$ formie aktu notarialnego, tj. zawsze $\mathrm{w}$ tych wypadkach, gdy przedmiotem umowy jest przeniesienie własności nieruchomości. Co do zasady notariusze konstruują umowę w taki sposób, aby nie budziła one wątpliwości co do sposobu jej kwalifikacji. Z praktyki orzeczniczej wynika jednak, że niestety nie zawsze tak jest. Niemniej jednak należy podkreślić, że powyżej określone zasady wykładni mają zastosowanie do każdej umowy zawartej w dowolnej formie prawnej, w tym także w formie aktu notarialnego ${ }^{24}$.

W dalszej części należy rozważyć, jak w kontekście umowy darowizny należy stosować powyższe dyrektywy wykładni. Podkreślam jednak, że należy unikać przy wykładni umowy dokonywania uogólnienia poprzez wskazanie jakichkolwiek kategorycznych twierdzeń. Należy pamiętać, że każdy przypadek jest inny i wymaga osobnej szczegółowej analizy. Niemniej jednak warto wskazać na te elementy

\footnotetext{
21 M. Safjan, [w:] K. Pietrzykowski (red.), Kodeks cywilny. Tom I. Komentarz, Warszawa 2004, s. 257.

22 Tak m.in. wyrok SN z dnia 8 czerwca 1999 r., II CKN 379/98, OSN 2000, Nr 1, poz. 10 z glosą aprobującą Z. Radwańskiego, OSP 2000, Nr 6, poz. 92.

23 Szerzej na ten temat zob. E. Rott-Pietrzyk, Wykładnia oświadczenia woli (studium prawnoporównawcze), SPP 2007, 3.

24 Tak m.in. wyrok SN z dnia 29 stycznia 2008 r., IV CSK 416/07, LEX nr 371413.
} 
stanu faktycznego, które mogą pojawić się w danym przypadku, a które nie mogą zostać pominięte czy zbagatelizowane przy dokonywaniu wykładni umowy.

\section{Badanie zamiaru i celu stron oraz kontekstu sytuacyjnego zawarcia umowy}

Z uwagi na fakt, że większość umów darowizny zawierana jest w stosunkach rodzinnych, to w większości przypadków strony przed jej spisaniem dokonują ustnych rokowań i ustaleń. Należy mieć przy tym na względzie charakter umowy darowizny, która w istocie swojej jest aktem szczodrobliwości. Z tego też względu szczególnej ochronie powinna podlegać realizacja woli darczyńcy. Należy więc w omawianych umowach analizować w szczególności wolę darczyńcy i ustalenia ustne poprzedzające spisanie umowy. W orzecznictwie przyjmuje się, że dopuszczalna i skuteczna jest taka konstrukcja umowy, w której przedmiotem darowizny uczynionej $w$ formie aktu notarialnego jest nieruchomość, a dodatkowo strony umowy $\mathrm{w}$ formie ustnej postanawiają, że obdarowany zobowiązany będzie do świadczenia pieniężnego na rzecz rodzeństwa obdarowanego, jakkolwiek obciążenia tego nie uwidoczniają $\mathrm{w}$ akcie notarialnym ${ }^{25}$.

Należy przy tym nadmienić, że art. 393 k.c. nie stawia umowie na rzecz osoby trzeciej żadnych wymagań co do jej treści lub formy. Jak słusznie zauważył Sąd Apelacyjny w Białymstoku w wyroku z dnia 5 czerwca 2013 r.: "Artykuł 393 k.c. nie stawia umowie na rzecz osoby trzeciej żadnych wymagań co do jej treści lub formy. Umowa ta podlega zatem takim ustawowym wymaganiom, jakie są przewidziane dla czynności prawnych w ogólności, oraz takim przesłankom, których spełnienia ustawa wymaga przy czynnościach prawnych danego rodzaju. [...] Zastrzeżenie spełnienia świadczenia na rzecz osoby trzeciej nie musi być przez strony uczynione wyraźnie. Wystarczy, jeżeli da się je ustalić w drodze interpretacji, zgodnie z dyrektywami wykładni oświadczeń woli sformułowanymi w art. 65 k.c., tj. w szczególności z uwzględnieniem okoliczności, w jakich strony złożyły oświadczenia woli, oraz z uwzględnieniem celu umowy (tak Sąd Najwyższy w wyr. z 9 stycznia 2003 r., I CK 329/02, OSN 2004, Nr 4, poz. 56. Podobne stanowisko zajmuje P. M., w Komentarzu k.c. pod red. E. G., t. I, s. 953)"26.

Analizując treść tych ustaleń rodzinnych, trzeba zwracać uwagę na to, czy stronom towarzyszył zamiar wiążącego zobowiązania obdarowanego do spłaty

\footnotetext{
25 Tak SN w wyroku z dnia 26 marca 1970 r., III CRN 78/70, OSNC 1971 Nr 2 poz. 33.

26 Wyrok SA w Białymstoku z dnia 5 czerwca 2013 r., I ACa 200/13, LEX nr 1324676.
} 
rodzeństwa, czy też było to jedynie niewiążące życzenie darczyńców. Należy badać także, czy cele $\mathrm{w}$ postaci obdarowania i w postaci wykonania świadczenia na rzecz nieobdarowanych były równoważne, czy też ten drugi cel miał charakter tylko uboczny. Za takim stanowiskiem opowiedział się m.in. A. Oleszko, wskazując, że to w przypadku darowizny z poleceniem głównym celem umowy jest świadczenie darczyńcy na rzecz obdarowanego, zaś polecenie przedstawia się tylko jako cel uboczny ${ }^{27}$.

Badając kontekst sytuacyjny zawarcia umowy, należy mieć także na uwadze świadomość prawną stron. Trzeba wziąć poprawkę, że osoby o niskiej lub znikomej wiedzy prawnej nie rozumieją ani niuansów prawnych ani instytucji prawa cywilnego, a tym samym w mniejszym stopniu mogą decydować o tym, jak sformułować odpowiednie postanowienia umowy, żeby jak najlepiej oddać swoją wolę i uzyskać najpełniejszą realizację zawartego między sobą porozumienia. W takich przypadkach zachodzi więc konieczność kierowania się przy dokonywaniu wykładni znaczenia umowy zgodnym zamiarem stron i celem umowy, nie zaś sposobem ujęcia postanowień umowy zawartych $w$ treści pisemnego porozumienia.

Jak wcześniej wskazywałam, błędem byłoby też skupianie się na brzmieniu umowy z pominięciem zamiaru stron. Niemniej jednak warto dodać w tym kontekście, że niezasadnym byłoby rozróżnianie konstrukcji polecenia od zobowiązania na rzecz osoby trzeciej w zależności od sformułowania, czy to darczyńca zobowiązuje obdarowanego, czy też to obdarowany się zobowiązuje. Takie skupienie się na treści umowy mogłoby prowadzić do wypaczenia zamiaru stron. Trzeba pamiętać, że umowę podpisują zawsze darczyńca i obdarowany. W każdym więc przypadku obdarowany godzi się na przyjęcie zobowiązania. Potwierdzeniem powyższej argumentacji jest uchwała Sądu Najwyższego z dnia 11 marca 1970 roku, w której wskazano, że: „obciążenie w umowie darowizny lub dożywocia nabywcy nieruchomości rolnej obowiązkiem zapłaty na rzecz osoby trzeciej określonej kwoty pieniężnej jest dopuszczalne"28. Uchwała zapadła na tle stanu faktycznego, w którym „małżonkowie P. przenieśli na swą córkę i zięcia własność nieruchomości rolnej, zobowiązując zarazem nabywców do wypłacenia trojgu pozostałym rodzeństwa po 15000 złotych". Przy analizowaniu brzmienia umowy warto natomiast zwracać uwagę na to, czy strony określiły termin realizacji świadczenia przez obdarowanego. Byłoby wszak zupełnie niepotrzebne zakreślanie w umowie terminu wykonania zobowiązania, gdyby miało ono stanowić tylko moralny obowiązek.

\footnotetext{
27 A. Oleszko, Szczególne konstrukcje umowy darowizny, „Palestra” 1976, 10, s. 26.

28 Uchwała SN z dnia 11 marca 1970 r., III CZP 28/70, OSNC 1971/10/171.
} 


\section{Ustalone zwyczaje}

Wykładni woli stron należy dokonywać również w świetle ustalonych zwyczajów. W tym względzie należy zauważyć, że przekazanie gospodarstwa rolnego jednemu z dzieci wraz z obowiązkiem spłaty pozostałego rodzeństwa jest typowe i powszechnie stosowane w warunkach wiejskich. Darowizna tego rodzaju wykorzystywana jest przez rolników do uregulowania całokształtu stosunków majątkowych rodziny. Jak słusznie zauważył A. Policiński, taka umowa jest rodzajem „wielostronnego paktu familijnego, w którym gospodarz wraz z małżonką i zstępnymi decyduje o losach gospodarstwa i swej rodziny" ${ }^{29}$. Także inni przedstawiciele doktryny zwrócili uwagę na powyższy zwyczaj. L. Stecki zauważył: „W praktyce w związku z dokonywanymi darowiznami coraz częściej stosuje się nie klasyczne polecenie, lecz dodatkowe zobowiązanie, stosownie do którego obdarowany ma spełnić oznaczone świadczenie na rzecz osoby trzeciej pojmowanej przez strony jako wierzyciel. Praktyka wskazuje na to, że darczyńcy chodzi z reguły o to, aby osoba trzecia rzeczywiście odniosła przewidzianą przez niego korzyść”30.

\section{Zakaz domniemywania polecenia}

Należy także wskazać, że w kontekście powyższych rozważań błędem byłoby także uznanie istnienia pewnego rodzaju domniemania prawnego zastosowania konstrukcji polecenia w umowie darowizny względem innych konstrukcji prawnych. Niezasadne byłoby przyjęcie, że muszą zaistnieć szczególne okoliczności przemawiające za wolą zastosowania przez strony konstrukcji zastrzeżenia świadczenia na rzecz osoby trzeciej, aby móc tak zakwalifikować dane postanowienie umowne, wykluczając polecenie. Takie twierdzenie nie ma bowiem wsparcia w żadnym przepisie prawa i jest sprzeczne z zasadą swobody umów wyrażoną w art. $353^{1}$ k.c. Jak słusznie zauważył M. Niedośpiał, „W umowie darowizny można zastrzec różne świadczenia na rzecz darczyńcy lub osób trzecich, np. obowiązek spłat na rzecz oznaczonych osób trzecich. W tym ostatnim przypadku, umowa w tej części jest umową na rzecz osoby trzeciej (art. 393 k.c.). [...] Dopuszczalna jest [...] tzw. darowizna obciążliwa, wynika to ze swobody umów (art. 3531, art. 58 k.c.). W umowie takiej darczyńca nakłada na obdarowanego obowiązek określonego świadczenia na rzecz darczyńcy lub osoby trzeciej. Podmioty te mają wierzytelność

29 Tak A. Policiński, glosa do wyroku SN z dnia 21 marca 1973 r., III CRN 40/73, OSP 1974, Nr 11, s. 230.

30 L. Stecki, Glosa do wyroku..., op. cit., s. 1478-1480. 
o spełnienie świadczenia"31. W tym względzie należy zwrócić uwagę, że konstrukcja polecenia w praktycznie identycznym brzmieniu występuje także $w$ treści art. 982 k.c. w ramach rozporządzenia na wypadek śmierci. W przypadku jednak rozporządzeń testamentowych obok polecenia testator może posłużyć się także konstrukcją zapisu zwykłego uregulowanego w art. 968 § 1 k.c. Zarówno zapis, jak i polecenie mogą dotyczyć obowiązku świadczenia majątkowego na rzecz określonej osoby. Rozróżnienie obu tych konstrukcji sprowadza się wówczas do ustalenia, czy wolą testatora było uczynienie czy nieuczynienie tych osób wierzycielami. W powyższej sytuacji tylko bowiem ten element różnicuje polecenie od zapisu w przypadku, gdy testator nie odwołał się do konkretnego przepisu ustawy. W doktrynie w odniesieniu do powyższych dwóch konstrukcji zwraca się uwagę na niedopuszczalność stosowania jakichkolwiek domniemań na rzecz którejkolwiek z nich. E. Gniewek słusznie zauważył: „Gdy działanie lub zaniechanie określone w rozporządzeniu testamentowym charakteryzuje się wartością majątkową, a przy tym ma nastąpić na rzecz lub w interesie osoby trzeciej, może pojawić się wątpliwość, czy jest to polecenie, czy zapis. Rozstrzygnięcie takiej kwestii wymaga każdorazowo uwzględnienia okoliczności konkretnego stanu faktycznego, by ustalić, czy według woli testatora osoba trzecia ma być wierzycielem (zapis), czy też nie (polecenie)"32. Analogicznie przy różnicowaniu konstrukcji polecenia i zastrzeżenia świadczenia na rzecz osoby trzeciej w umowie darowizny, przy braku literalnego odwołania się do jednej z tych konstrukcji prawnych, nie można domniemywać, że wolą darczyńców było nieuczynienie z osób trzecich wierzycieli obdarowanego.

\section{Wnioski końcowe}

Podsumowując powyższą argumentację, wyrażam pogląd, że w umowie darowizny dopuszczalne jest posłużenie się zarówno konstrukcją polecenia (art. 893 k.c.), jak i zobowiązania na rzecz osoby trzeciej (art. 393 k.c.). W celu dokonania prawidłowej subsumpcji należy kierować się zasadami wykładni umów zawartymi $\mathrm{w}$ art. $65 \S 2$ k.c., badając przede wszystkim zgodny zamiar stron i cel umowy. Niedopuszczalne jest $\mathrm{w}$ tym zakresie stosowanie domniemania istnienia polecenia. Obie konstrukcje prawne są równie dopuszczalne w myśl zasady swobody umów.

Prawidłową wykładnią art. 893 i 894 k.c. jest uznanie, że polecenie w umowie darowizny tworzy zobowiązanie prawne, tj. takie, którego można skutecznie dochodzić na drodze sądowej. Opowiadam się więc za tzw. zaskarżalnością polecenia.

\footnotetext{
31 M. Niedośpiał, Glosa do wyroku SA w Katowicach..., op. cit.

32 E. Gniewek, Kodeks cywilny. Komentarz, Warszawa 2006, s. 1500.
} 
Uważam jednak, że uprawnienie to przysługuje tylko podmiotom z kręgu osób określonych w art. 894 k.c.

W przypadku zatem dokonania subsumpcji umowy jako polecenia, należy uznać, że realizacji polecenia może dochodzić darczyńca, a po jego śmierci jego spadkobiercy, a jeżeli polecenie ma na względzie interes społeczny - także właściwy organ państwowy. Polecenia na drodze sądowej nie może dochodzić osoba trzecia, na rzecz której polecenie ustanowiono (za wyjątkiem sytuacji, gdy występuje jako spadkobierca darczyńcy). W przypadku zaś dokonania subsumpcji jako umowy darowizny z zastrzeżeniem świadczenia na rzecz osoby trzeciej, realizacji świadczenia może żądać zarówno darczyńca, jak i ta osoba trzecia.

\section{Bibliografia}

Bednarek M., [w:] E. Łętowska (red.), System Prawa Prywatnego. Tom 5. Prawo zobowiązań - część ogólna, Warszawa 2006.

Gniewek E., Kodeks cywilny. Komentarz, Warszawa 2006.

Grzybowski S., [w:] S. Grzybowski (red.), System Prawa cywilnego, t. III, cz. 2, Wrocław 1976.

Karasek-Wojciechowicz I., Roszczenie o wykonanie zobowiązania z umowy zgodnie z jego treścią, Warszawa 2014.

Księżak P., Żądanie wykonania polecenia, PS 2006, Nr 4.

Kubas A., Umowa na rzecz osoby trzeciej, ZNUJ, Warszawa-Kraków 1976, Prace Prawnicze, z. 78.

Longchamps de Berier F., O elastyczności prawa spadkowego: fideikomis uniwersalny w klasycznym prawie rzymskim, Warszawa 2006.

Longchamps de Berier R., Uzasadnienie projektu kodeksu zobowiqzań z uwzględnieniem ostatecznego tekstu kodeksu. Art. 1-167, Warszawa 1934.

Łętowska E., [w:] E Łętowska (red.), System Prawa Prywatnego. Tom 5. Prawo zobowiązań - część ogólna, Warszawa 2006.

Machnikowski P., [w:] E Łętowska (red.), System Prawa Prywatnego. Tom 5. Prawo zobowiqzań - część ogólna, Warszawa 2006.

Niedośpiał M., Glosa do wyroku SA w Katowicach z dnia 3 lutego 1995 r., I ACr 656/94, OSA 1997, Nr 10, OSA 1997/10/75.

Ohanowicz A., [w:] A. Ohanowicz, Z. Górski, Zarys prawa zobowiązań, Warszawa 1970.

Oleszko A., Szczególne konstrukcje umowy darowizny, „Palestra” 1976, 10.

Policiński A., Glosa do wyroku SN z dnia 21 marca 1973 r., III CRN 40/73, OSP 1974, Nr 11.

Radwański Z., [w:] Z. Radwański (red.), System Prawa Prywatnego, Tom 2, Prawo cywilne - część ogólna, Warszawa 2008.

Rejman S., [w:], Z. Resich (red.), Kodeks cywilny. Komentarz, t. 2, Warszawa 1972. 


\section{KATARZYNA EGER}

Rott-Pietrzyk E., Wykładnia oświadczenia woli (studium prawnoporównawcze), SPP 2007, 3.

Rzetecka-Gil A., Kodeks cywilny. Komentarz. Zobowiązania - część ogólna, wydanie tylko elektroniczne LEX/el., 2011.

Safjan M., [w:] K. Pietrzykowski (red.), Kodeks cywilny. Tom I. Komentarz, Warszawa 2004. Safjan M., [w:] K. Pietrzykowski (red.), Kodeks cywilny. Tom II. Komentarz, Warszawa 2004. Sokołowski K., Darowizna z poleceniem a negotium mixtum cum donatione w praktyce notarialnej, „Rejent” 2011, 4.

Stecki L., Glosa do wyroku SN z dnia 21 marca 1973 r., III CRN 40/73, NP 1975, Nr 10-11. 